\title{
In Vitro Cytotoxic Activity of Clinacanthus nutans Leaf Extracts Against HeLa Cells
}

\author{
Nor Hasyimah Haron ${ }^{1}$, Zaleha Md Toha ${ }^{1}$, Rafedah Abas ${ }^{1}$, Mohammad Razak \\ Hamdan $^{2}$, Nizuwan Azman', Melati Khairuddean ${ }^{3}$, Hasni Arsad ${ }^{1 *}$
}

\begin{abstract}
Objective: This study was conducted to investigate the antiproliferative activity of extracts of Clinacanthus nutans leaves against human cervical cancer (HeLa) cells. Methods: C. nutans leaves were subjected to extraction using $80 \%$ methanol or water. The methanol extract was further extracted to obtain hexane, dichloromethane (DCM), and aqueous fractions. The antiproliferative activity of the extracts against HeLa cells was determined. The most cytotoxic extract was furthered analyzed by apoptosis and cell cycle assays, and the phytochemical constituents were screened by gas chromatography-mass spectrometry (GC-MS). Results: All of the extracts were antiproliferative against HeLa cells, and the DCM fraction had the lowest $\mathrm{IC}_{50}$ value of $70 \mu \mathrm{g} / \mathrm{mL}$ at $48 \mathrm{~h}$. Microscopic studies showed that HeLa cells exposed to the DCM fraction exhibited marked morphological features of apoptosis. The flow cytometry study also confirmed that the DCM fraction induced apoptosis in HeLa cells, with cell cycle arrest at the S phase. GC-MS analysis revealed the presence of at least 28 compounds in the DCM fraction, most of which were fatty acids. Conclusion: The DCM fraction obtained using the extraction method described herein had a lower $\mathrm{IC}_{50}$ value than those reported in previous studies that characterized the anticancer activity of $C$. nutans against HeLa cells.
\end{abstract}

Keywords: Clinacanthus nutans- phytochemical constituents- antiproliferative- apoptosis

Asian Pac J Cancer Prev, 20 (2), 601-609

\section{Introduction}

The second leading cause of death in the world is cancer, and it is estimated that cancer will contribute to 9.6 million deaths in 2018 (Bray et al., 2018). Numerous factors are involved in cancer development, including genetics, health, nutrition, personal habits, and the environment. Cervical cancer is the fourth most common cancer among women globally; about 570,000 new cases were reported in 2018, representing $6.6 \%$ of all female cancers. Currently, the recommended treatment programme for this cancer involves surgery, chemotherapy, radiation, or other methods (World Health Organization, 2018). Herbal medicine has been increasingly recognized as a useful complementary and alternative therapy for patients with cancer. Numerous clinical studies have reported the positive effects of herbal medicines when taken with conventional therapeutics, in particular in terms of survival rate, the immune system, and quality of life of cancer patients (Yin et al., 2013).

Clinacanthus nutans (Burm. F.) Lindau (CN), a medicinal herb that belongs to the Acanthaceae family, is one such natural product that might be effective in treating cancers, including human cervical cancer. Its leaf extract was effective in treating genital herpes, one of the leading causes of cervical cancer, by shortening duration of infection and reducing its severity (Sakdarat et al., 2006). Results of in vitro studies showed that $\mathrm{CN}$ was virucidal against herpes simplex virus (Jayavasu et al., 1992) and varicella zoster virus (Thawaranantha et al., 1992). In Malaysia, Singapore, and Thailand, an herbal tea made from the $\mathrm{CN}$ leaf is a traditional herbal remedy used to treat cancer patients. Some patients claimed to have recovered due to consistent and abundant consumption of CN juice or tea (Poonthananiwatkul et al., 2015; Siew et al., 2014).

Numerous in vitro studies have reported antiproliferative and cytotoxic activities of $\mathrm{CN}$ extracts. For example, Yong et al., (2013) reported that the chloroform extract of CN had the greatest antiproliferative effect against the human erythroleukemia K-562 cell line $\left(\mathrm{IC}_{50}: 47.70 \mu \mathrm{g} / \mathrm{mL}\right)$ and the human Burkitt's lymphoma Raji cell line $\left(\mathrm{IC}_{50}: 47.31\right.$ $\mu \mathrm{g} / \mathrm{mL}$ ) but not against the human neuroblastoma IMR-32 cell line. Quah et al., (2017) found that the methanol extract of $\mathrm{CN}$ showed cytotoxic activity against Hep $\mathrm{G} 2$ and MDA-MB-231 cells $\left(\mathrm{IC}_{50} \mathrm{~s}: 13.3\right.$ and $18.7 \mu \mathrm{g} /$ $\mathrm{mL}$, respectively) but not against A549, HT-29, MCF-7, and CRL 1739 cells. Additionally, extracts of different plant parts (e.g., leaf, bark, stem, and roots) may have different effects on cancer cells. Arullappan et al., (2014) 
reported that the petroleum ether extract from $\mathrm{CN}$ leaves was cytotoxic against human cervical cancer (HeLa) cells $\left(\mathrm{IC}_{50}: 18 \mu \mathrm{g} / \mathrm{mL}\right)$ but the stem extract was not $\left(\mathrm{IC}_{50}\right.$ : $>100 \mu \mathrm{g} / \mathrm{mL}$ ). However, the ethyl acetate extract from the stem was cytotoxic $\left(\mathrm{IC}_{50}: 20 \mu \mathrm{g} / \mathrm{mL}\right.$ ) when compared to that of the leaf $\left(\mathrm{IC}_{50}: 92 \mu \mathrm{g} / \mathrm{mL}\right)$ against the same cells (Arullappan et al., 2014).

The anticancer effects of $\mathrm{CN}$ may be due to its active compounds, and these effects may be further influenced by the type of extraction, solvent, and plant part used. For example, Khoo et al., (2015) reported that the terpenoids and sulfur-containing glucosides present in extracts of dried CN leaves were the main components responsible for in vitro antioxidant and $\alpha$-glucosidase inhibitory effects. Teshima et al., (1997) identified six known C-glycosyl flavones (vitexin, isovitexin, shaftoside, isomollupentin 7-O- $\beta$-glucopyranoside, orientin, and iso-orientin) from the butanol and water-soluble portions of the methanol extract of $\mathrm{CN}$ stems and leaves. The presence of these compounds indicates that $\mathrm{CN}$ possesses important biological activities, including antimicrobial, hepatoprotective, antioxidant, anti-inflammatory, and anti-neoplastic properties.

This study was conducted to evaluate the in vitro antiproliferative activity of different solvent extracts of $\mathrm{CN}$ leaves against HeLa cells, which represent a human cancer cell model, in order to compare the bioacitivities of different solvent extracts. The most cytotoxic fraction was further analyzed using apoptosis and cell cycle phase assays, which are commonly used to determine how effective herbal remedies are against cancer cells. The compounds in this fraction also were analyzed using gas chromatography-mass spectrometry (GC-MS).

\section{Materials and Methods}

\section{Plant material}

Fresh aerial parts of $\mathrm{CN}$ were collected at the HERBagus Sdn. Bhd. farm located at Pongsu Seribu, Kepala Batas, Penang, Malaysia (5'29'47.9'”N 100²6'43.2'”E). Samples containing leaves, stem, and root were identified and authenticated by the School of Biological Sciences, Universiti Sains Malaysia (deposited voucher number 11536 for reference). The leaves were separated from the stems and washed thoroughly with tap water followed by distilled water. The leaves were then stored at $-80^{\circ} \mathrm{C}$ prior the extraction process.

\section{Preparation of $\mathrm{CN}$ extracts}

$80 \%$ methanol and fractioned [hexane, dichloromethane (DCM), and aqueous] extracts.

About $250 \mathrm{~g}$ of fresh $\mathrm{CN}$ leaves were blended into small pieces, soaked in $80 \%$ methanol for $24 \mathrm{~h}$ at room temperature, and filtered. The soaking process was repeated twice to ensure exhaustive extraction. The filtrate was concentrated in vacuo at $40^{\circ} \mathrm{C}$ to about $1 / 10$ of the original volume and freeze-dried to obtain the $80 \%$ methanol crude extract. A large portion of this crude extract was partitioned with hexane $(3 \times 800 \mathrm{~mL})$ and DCM $(3 \times 800 \mathrm{~mL})$ by liquid-liquid extraction (Figure 1). These solvent fractions (hexane and DCM) together with the residual aqueous portion were concentrated to dryness in vacuo.

\section{Water extract}

About $500 \mathrm{~g}$ of fresh $\mathrm{CN}$ leaves were blended into small pieces, soaked in distilled water for $24 \mathrm{~h}$ at room temperature, and filtered. This process was repeated twice. The filtrate then was freeze-dried to obtain the crude extract.

\section{Cell line and culture}

HeLa cells (ATCC ${ }^{B} C C L-2^{\text {TM }}$ ) were purchased from the American Type Culture Collection (Manassas, VA, USA). Cells were cultured in Dulbecco's modified eagle medium supplemented with $10 \%$ fetal bovine serum and $1 \%$ penicillin-streptomycin. Growth was maintained at $37^{\circ} \mathrm{C}$ in a humidified incubator containing $5 \% \mathrm{CO}_{2}$. Cells were within 13 passages when the experiment was conducted.

\section{Antiproliferation assay}

All CN extracts were tested for antiproliferative activity against HeLa cells using the Sulforhodamine B (SRB) assay according to the previously described protocol (Skehan et al., 1998). Briefly, cells (2.5 x 104 cells $/ \mathrm{mL}$ ) were incubated in 96-well plates with a serial dilution of extracts starting with $4,000 \mu \mathrm{g} / \mathrm{mL}$ (water, $80 \%$ methanol, and its aqueous fraction) or $250 \mu \mathrm{g} / \mathrm{mL}$ (hexane and DCM fractions of the methanol extract) for 24,48 , and $72 \mathrm{~h}$ at $37^{\circ} \mathrm{C}$ with $5 \% \mathrm{CO}_{2}$. The cells were fixed with $50 \mu \mathrm{L}$ of $50 \%$ cold trichloroacetic acid for $30 \mathrm{~min}$ at room temperature followed by gentle tap water washing $(5 x)$ and then drying. Cells were then stained with $100 \mu \mathrm{l}$ of $0.4 \%$ $\mathrm{SRB}$ in $1 \%$ acetic acid for $30 \mathrm{~min}$, followed by washing with $1 \%$ acetic acid (4x). The plate was dried, $100 \mu \mathrm{L}$ of $10 \mathrm{mM}$ Tris buffer were added to each well, and the plate was shaken for $5 \mathrm{~min}$. Relative cell viability was measured by scanning at $540 \mathrm{~nm}$ on a microplate reader (Bio-Tek ${ }^{\circledR}$ Instruments, Inc., Winooski, VT, USA). The cytotoxicity was determined using the previously described formula (Bendale et al., 2017):

Cytotoxicity $(\%)=$ Optical density of (sample - blank $) /$ Optical density of (control - blank) X 100

The inhibition concentration of extract that is able to inhibit cell proliferation by $50 \%\left(\mathrm{IC}_{50}\right)$ was calculated graphically from the cell proliferation curve. The extract at the time point with the lowest $\mathrm{IC}_{50}$ value was selected for further analysis.

\section{Annexin $V$ analysis of apoptosis}

Analysis of apoptosis in HeLa cells treated with the selected extract was performed using the Annexin V-FITC kit (Miltenyl Biotec GmbH, Bergisch Gladbach, Germany; Cat. No.: 130-092-052) via flow cytometry. HeLa cells $\left(3.7 \times 10^{4}\right.$ cells $/ \mathrm{mL}, 6 \mathrm{~mL} /$ flask) were incubated with three different doses $(62.5,125.0$, and $250.0 \mu \mathrm{g} / \mathrm{mL})$ of the selected extract for $48 \mathrm{~h}$ at $37^{\circ} \mathrm{C}$ with $5 \% \mathrm{CO}_{2}$. All cells were harvested, including floating and adhering cells, after washing once with phosphate buffered saline (PBS). About 
$4 \times 10^{5}$ cells were resuspended in $100 \mu 1$ of binding buffer with $10 \mu \mathrm{l}$ of Annexin V-FITC. The cells were washed with binding buffer after 15 min of incubation in the dark at room temperature, and $5 \mu$ lof propidium iodide solution then were immediately added prior to analysis by FACS Calibur flow cytometry (BD Biosciences, San Diego, CA, USA). A minimum of three independent replicates were analyzed using Mulltiset software. The percentages of viable, early apoptotic, late apoptotic, and necrotic cells were determined for a total of 10,000 events per sample.

\section{Morphological analysis}

Morphological changes of HeLa cells treated with the selected extract were observed by phase contrast microscopy using a Zeiss Axio Observer Z1 (Carl Zeiss AG, Jena, Germany) and an Operetta high-content imaging system (Perkin Elmer, Buckinghamshire, UK) for fluorescent microscopy. HeLa cells $\left(2.5 \times 10^{4}\right.$ cell/ $\mathrm{mL}, 0.1 \mathrm{~mL} /$ well) were incubated in a 96-well plate with $0.2 \mathrm{~mL} /$ well of three different doses $(62.5,125.0$, and $250.0 \mu \mathrm{g} / \mathrm{mL}$ ) of the selected extract of $\mathrm{CN}$ for $48 \mathrm{~h}$ at $37{ }^{\circ} \mathrm{C}$ with $5 \% \mathrm{CO}_{2}$. The cells were directly imaged for phase contrast microscopy, whereas Hoechst 33,342 dye (Invitrogen, Paisley, UK; Cat. No.: H1399) was applied for fluorescent microscopy following the manufacturer's instructions. The cells were stained with $0.5 \mu \mathrm{L}$ dye $(0.4$ $\mathrm{mg} / \mathrm{mL}$ ) and incubated for $15 \mathrm{~min}$ prior to viewing.

\section{Cell cycle analysis}

HeLa cells $\left(3.7 \times 10^{4}\right.$ cells $/ \mathrm{mL}, 6 \mathrm{~mL} /$ flask $)$ were incubated with the selected extract at the $\mathrm{IC}_{50}$ dose for 24 , 48 , and $72 \mathrm{~h}$ at $37^{\circ} \mathrm{C}$ with $5 \% \mathrm{CO}_{2}$. The cells were then collected by trypsinization with Accutase (Nacalai Tesque, Kyoto, Japan; Cat. No.: 12679-54), washed in PBS, and fixed in $70 \%$ cold ethanol. Thereafter, the cells were stained using FxCycleTM PI/RNase staining solution (Life Technologies Corporation, Carlsbad, CA, USA; Cat. No.: F10797) following the manufacturer's protocol. A FACS Calibur flow cytometer (BD Biosciences) was used to determine the distribution of cells in different stages of the cell cycle. The percentage of cells in the G1, S, and G2/M phases was calculated using ModFit LT software (Verity Software House, Topsham, Maine, USA).

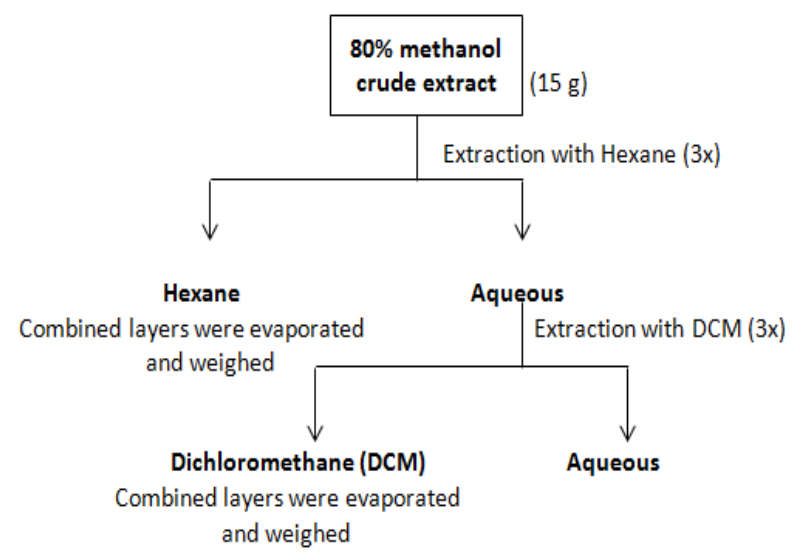

Figure 1. Flow Diagram Showing the Partitioning Extraction of the Aqueous Methanol Extract of $\mathrm{CN}$ by Liquid-Liquid Extraction
GC-MS analysis

The selected $\mathrm{CN}$ extract was analyzed based on the optimized method using an Agilent 6890/5973 GC-MS system (Santa Clara, CA, USA). The separation was performed with an HP-5MS capillary column $(30 \mathrm{~m} \times 0.25 \mathrm{~mm} \times 0.25 \mu \mathrm{m})$. The injector was set at $325^{\circ} \mathrm{C}$ (split mode with the ratio adjusted to $5: 1$, injection volume $=1 \mu \mathrm{L}$ ). The oven temperature started at $70^{\circ} \mathrm{C}$ for $2 \mathrm{~min}$, increased to $280{ }^{\circ} \mathrm{C}$, then was held for $20 \mathrm{~min}$ at $20^{\circ} \mathrm{C} \mathrm{ramp} / \mathrm{min}$. The flow rate of the carrier gas (helium) was maintained at $1.2 \mathrm{~mL} / \mathrm{min}$. The mass spectrometer was operated with ionization in the electron impact mode using $70 \mathrm{eV}$ (ionization energy) to obtain the mass spectra that ranged from m/z 40 to 700 . Identifications were made by comparison with NIST library data.

\section{Statistical analysis}

The $\mathrm{IC}_{50}$ values of the antiproliferative activity of the extracts against HeLa cells were estimated from the dose-response curves. The experiments were repeated at least three times, with three samples for each repeat. The results are expressed as means \pm standard deviation (SD). The data were analyzed using one-way analysis of variance to identify significant differences among groups. $\mathrm{p}<0.05$ was considered to be statistically significant. Analysis of the data was performed using SPSS statistical software version 22.0 (IBM Corporation, Armonk, NY, USA).

\section{Results}

Antiproliferative activity of CN extracts against HeLa cells Table 1 presents the $\mathrm{IC}_{50}$ values of the $\mathrm{CN}$ extracts against HeLa cells, and Figure 2 shows the antiproliferative effects of the extracts. All extracts showed significant antiproliferative activity against HeLa cells in a dose- and time-dependent manner. The non-polar (hexane) and semi-polar (DCM) fractions had lower $\mathrm{IC}_{50}$ values than the other (polar) extracts. The DCM fraction had the highest toxicity against $\mathrm{HeLa}$, with the lowest $\mathrm{IC}_{50}$ value $(70 \mu \mathrm{g} / \mathrm{mL})$ occurring at $48 \mathrm{~h}$ of treatment. Thus, treatment of HeLa cells with the DCM fraction for $48 \mathrm{~h}$ was selected for further analysis.

Evaluation of apoptosis by flow cytometric analysis

After treatment of HeLa cells with $62.5 \mu \mathrm{g} / \mathrm{mL}$ of the DCM fraction for $48 \mathrm{~h}, 55 \%$ of the cells were viable, $38 \%$

Table 1. $\mathrm{IC}_{50}(\mu \mathrm{g} / \mathrm{mL})$ of CN Leaf Extracts on HeLa Cells

\begin{tabular}{lccc}
\hline & \multicolumn{3}{c}{$\mathrm{IC}_{50} *(\mu \mathrm{g} / \mathrm{mL})$} \\
\hline Time of treatment $(\mathrm{h})$ \\
\hline Hexane & 24 & 48 & 72 \\
DCM & 200 & 185 & 170 \\
Aqueous & 100 & 70 & 80 \\
Crude 80\% MeOH & 1,300 & 650 & 650 \\
Crude water & 4,000 & 1,800 & 1,500 \\
*IC half maximal inhibitory concentration
\end{tabular}

Asian Pacific Journal of Cancer Prevention, Vol 20 
Table 2. Phytoconstituents Identified in the DCM Fraction of the CN Leaf Extract by GC-MS

\begin{tabular}{|c|c|c|c|c|c|}
\hline Peak no. & Identified/Similar compounds & $\begin{array}{l}\text { Molecular mass } \\
(\mathrm{g} \text { mol-1) }\end{array}$ & RT & $\begin{array}{l}\text { Area } \\
(\%)\end{array}$ & Compound nature \\
\hline 1 & Cyclohexane, isocyanato- & 125.084 & 4.453 & 0.09 & Hexahydrobenzene \\
\hline 2 & Sulfuric acid, dimethyl ester & 126.132 & 5.078 & 0.22 & Diester \\
\hline 3 & Naphthalene, 1,2-dihydro-1,1,6-trimethyl- & 172.125 & 7.473 & 0.19 & Aromatic hydrocarbon \\
\hline 4 & Cyclodecane & 140.27 & 8.16 & 0.18 & Monocyclic alkane \\
\hline 5 & Butylated hydroxytoluene & 220.183 & 8.479 & 0.3 & Phenol derivative \\
\hline 6 & $\begin{array}{l}\text { 2-propenoic acid, 3-(3-hydroxyphenyl)-, methyl } \\
\text { ester }\end{array}$ & 178.063 & 9.285 & 0.08 & Phenolic \\
\hline 7 & 1-Tridecene & 182.203 & 9.389 & 0.16 & Acyclic olefins; alkenes \\
\hline 8 & 4-((1E)-3-hydroxy-1-propenyl)-2-methoxyphenol & 180.079 & 9.84 & 0.79 & Phenolic \\
\hline 9 & Pentadecanoic acid, 14-methyl-, methyl ester & 270.256 & 10.722 & 2.48 & Fatty acid \\
\hline 10 & n-hexadecanoic acid & 256.24 & 10.895 & 1.95 & Fatty acid \\
\hline 11 & Heptadecanoic acid, methyl ester & 284.272 & 11.215 & 0.29 & Fatty acid \\
\hline 12 & Triphenylmethane & 244.125 & 11.291 & 0.19 & Hydrocarbon \\
\hline 13 & 1,3-dicyclohexylurea & 224.35 & 11.499 & 0.19 & Urea \\
\hline 14 & 9,12-octadecadienoic acid, methyl ester & 294.256 & 11.569 & 1.22 & Fatty acid \\
\hline 15 & $\begin{array}{l}\text { 9,12,15-octadecatrienoic acid, methyl ester, } \\
(\mathrm{Z}, \mathrm{Z}, \mathrm{Z}) \text { - }\end{array}$ & 292.24 & 11.603 & 3.34 & Fatty acid \\
\hline 16 & Phytol & 296.308 & 11.652 & 1.15 & Diterpene alcohol \\
\hline 17 & Octadecanoic acid, methyl ester & 298.287 & 11.694 & 1.12 & Fatty acid \\
\hline 18 & 7,10,13-hexadecatrienoic acid, methyl ester & 264.4 & 11.777 & 0.58 & Fatty acid \\
\hline 19 & Octadecanoic acid & 284.484 & 11.853 & 0.72 & Fatty acid \\
\hline 20 & 1-methyl-10,18-bisnorabieta-8,11,13-triene & 256.219 & 12.048 & 0.15 & Other organic compounds \\
\hline 21 & $\begin{array}{l}\text { 1,2-benzenedicarboxylic acid, mono(2-ethylhexyl) } \\
\text { ester }\end{array}$ & 278.152 & 13.714 & 1.61 & $\begin{array}{l}\text { Ester derivative of } \\
\text { benzoic acid }\end{array}$ \\
\hline 22 & Hexadecane & 226.44 & 13.915 & 0.42 & Alkane hydrocarbon \\
\hline 23 & N-(4-methoxyphenyl)-2-hydroxyimino-acetamide & 194.069 & 14.436 & 4.72 & Acetamide \\
\hline 24 & $\begin{array}{l}\text { 9,12-octadecadienoic acid (Z,Z)-, 2-hydroxy-1- } \\
\text { (hydroxymethyl)ethyl ester }\end{array}$ & 354.277 & 14.589 & 3.16 & Fatty acid \\
\hline 25 & $\begin{array}{l}\text { Nonanoic acid, } \\
\text { 9-(3-hexenylidenecyclopropylidene)-, 2-hydroxy- } \\
\text { 1-(hydroxymethyl)ethyl ester, (Z,Z,Z)-cont. }\end{array}$ & 352.261 & 14.658 & 2.74 & Fatty acid \\
\hline 26 & 13-Docosenamide, $(\mathrm{Z})$ - & 337.334 & 15.248 & 2.98 & Fatty acid amides \\
\hline 27 & Vitamin E & 430.381 & 19.476 & 0.64 & $\begin{array}{l}\text { Tocopherols and } \\
\text { tocotrienols }\end{array}$ \\
\hline 28 & Stigmasterol & 412.702 & 21.94 & 0.58 & $\begin{array}{l}\text { Phytosterol (steroid } \\
\text { derivative) }\end{array}$ \\
\hline
\end{tabular}

were in early apoptosis, $5 \%$ were in late apoptosis, and $1 \%$ exhibited necrosis (Figure 3). Treatment with 125 $\mu \mathrm{g} / \mathrm{mL}$ of the DCM fraction increased the percentage of cells in late apoptosis (12\%), and $70 \%$ of cells were in late apoptosis when treated with $250 \mu \mathrm{g} / \mathrm{mL}$ of the DCM fraction. The percentage of necrotic cells was less than $12 \%$ for all treatments.

\section{Morphological analysis}

HeLa cells treated with 62.5, 125.0, and $250.0 \mu \mathrm{g} /$ $\mathrm{mL}$ of the DCM fraction of $\mathrm{CN}$ leaves showed reduced cell viability with increasing dose when compared with untreated cells ((Figure 4A(i)). Phase contrast microscopy showed that untreated HeLa cells were characterized by an organized monolayer with a regular polygonal appearance. After treatment, the cells became rounded and disconnected from each other and exhibited cellular shrinkage and nuclear condensation. Fluorescent microscopy with Hoechst 33,342 staining then was used to determine if the DCM fraction induced apoptosis in HeLa cells. Untreated HeLa cells remained uniformly stained blue ((Figure 4B(i)). Cells treated with $62.5 \mu \mathrm{g} /$ $\mathrm{mL}$ of the extract showed some chromatin condensation and DNA fragmentation, which are the hallmarks of apoptotic cells. A number of cells with similar changes were observed in the $125 \mu \mathrm{g} / \mathrm{mL}$ treatment. At $250 \mu \mathrm{g} / \mathrm{mL}$ of the extract, most cells showed apoptotic body formation with decreased cell viability, indicating that induction of apoptosis was dose-dependent.

\section{Cell cycle analysis}

The $\mathrm{IC}_{50}$ concentration of the DCM fraction of $\mathrm{CN}$ at $48 \mathrm{~h}(70 \mu \mathrm{g} / \mathrm{mL})$ was used to evaluate the effects of the extract on the cell cycle of HeLa cells over time. A 


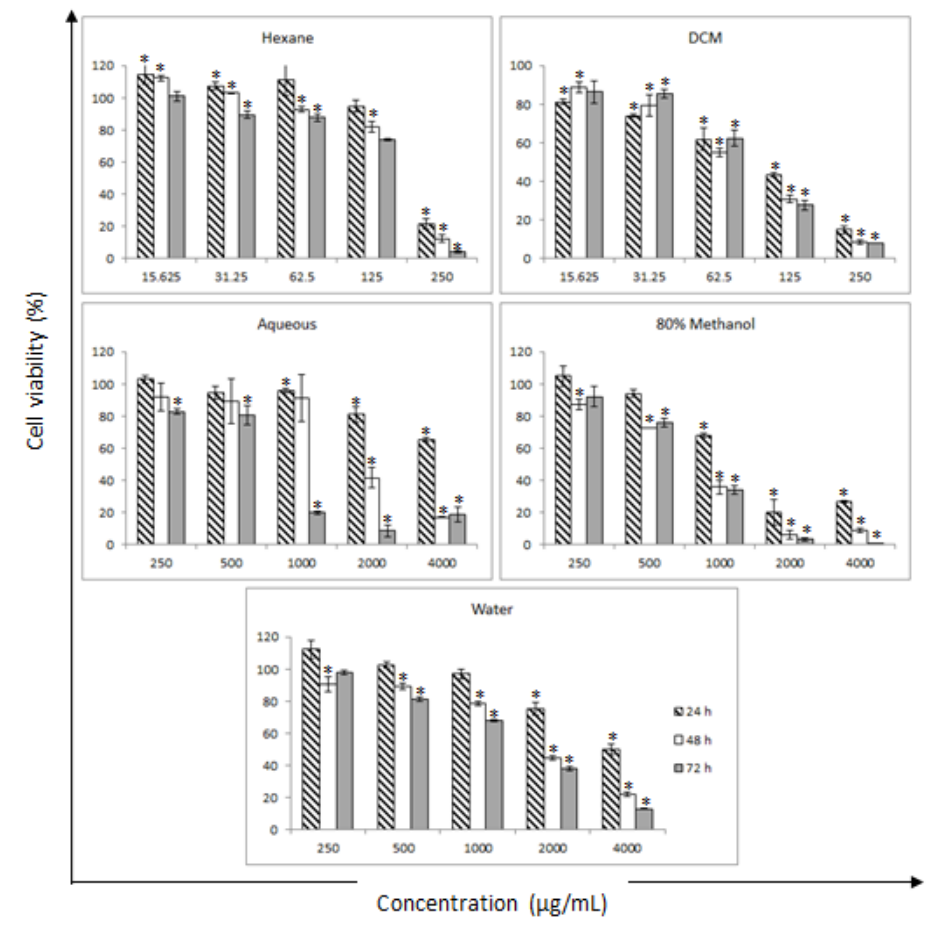

Figure 2. Antiproliferative Effects of $\mathrm{CN}$ Extracts on HeLa Cells. The cells were incubated with increasing concentrations of different solvent extracts (hexane, DCM, aqueous, $80 \%$ methanol, and water) for 24, 48, and $72 \mathrm{~h}$, and cell viability was determined by the SRB assay. All values given are means \pm SDs. Asterisks signify statistical significance at $\mathrm{p}<0.05$ compared to the untreated HeLa cells $(100 \%$ viability).
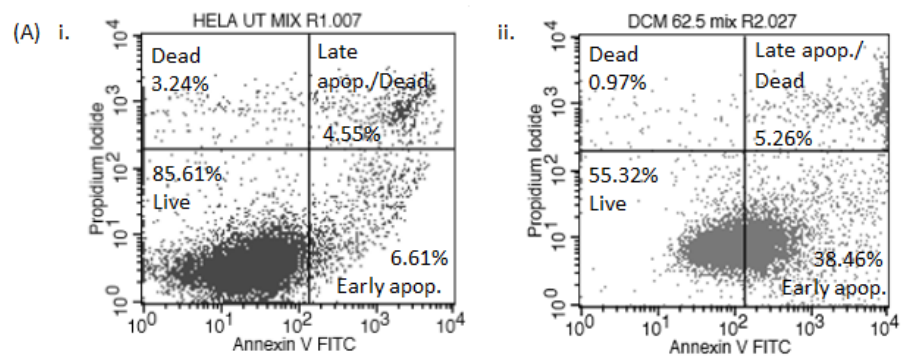

iii.
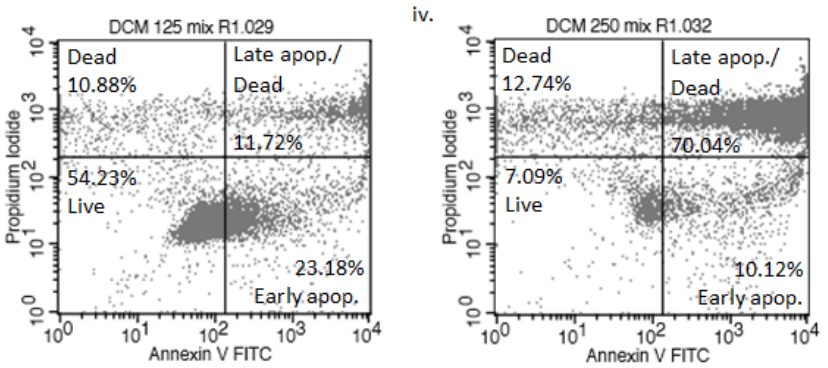

(B)

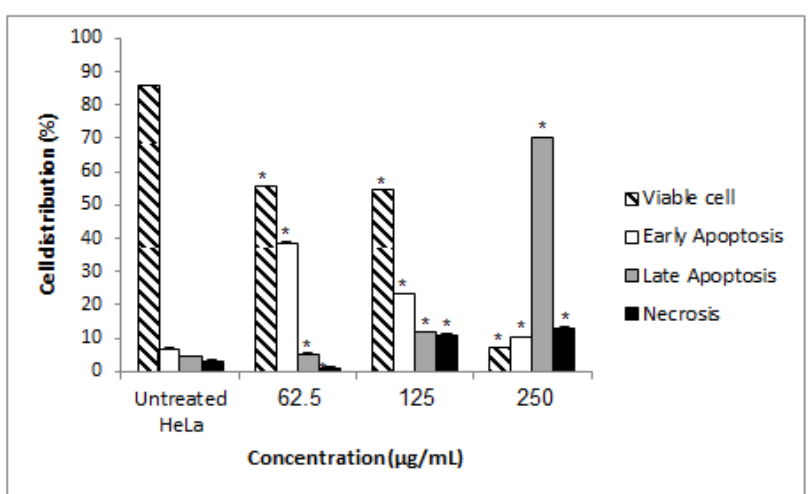

Figure 3. Dot Plots (A) of untreated HeLa cells (i) and HeLa cells (ii, iii, and iv) treated with 62.5, 125, and 250 $\mu \mathrm{g} /$ $\mathrm{ml}$ of the DCM fraction of the CN extract, respectively, and the percentage (\%) of cell distribution (B) of HeLa cells after treatment with the DCM fraction as determined by Annexin V-FITC and PI staining. Asterisks signify statistical significance at $\mathrm{p}<0.05$ compared to untreated HeLa cells. 
A
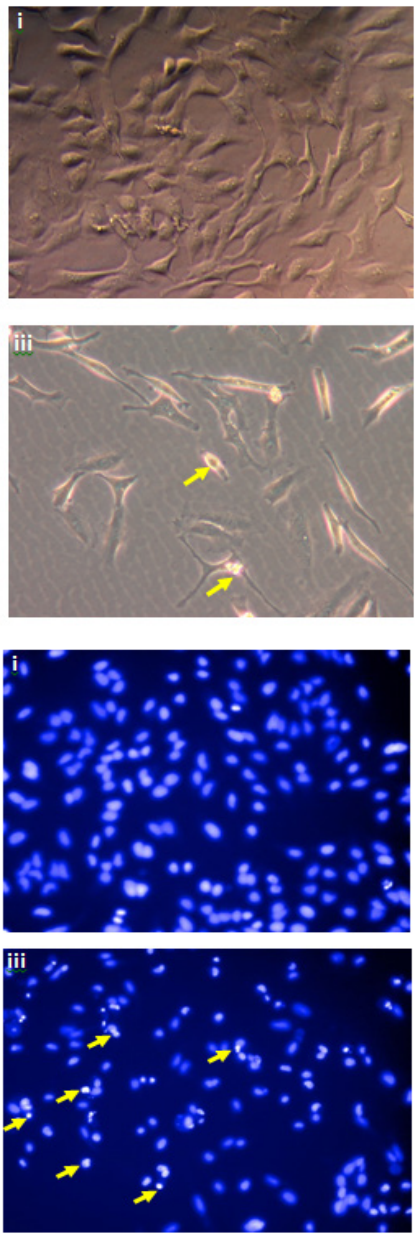
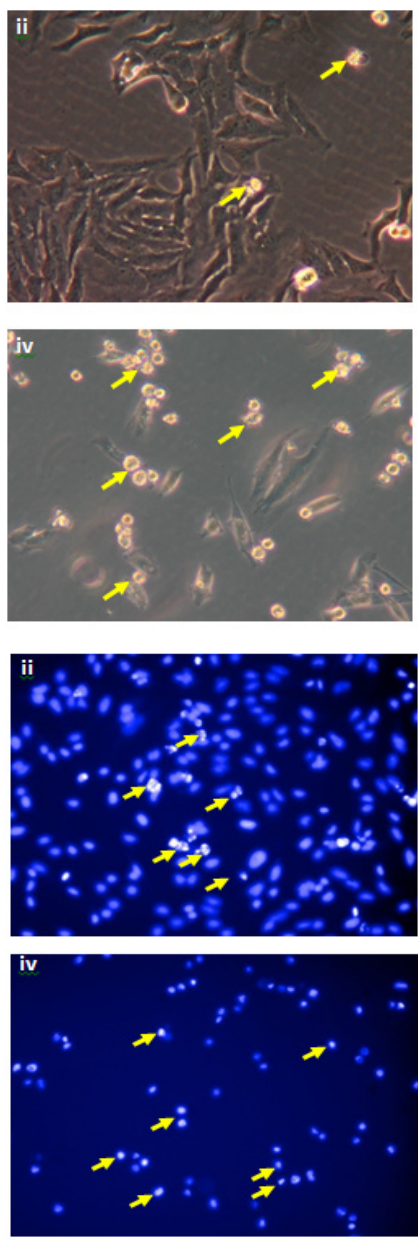

Figure 4. Representative Images Showing Morphological Changes of HeLa Cells Detected by (A) phase contrast microscope and (B) fluorescent microscope (Hoechst 33342): (i) Untreated HeLa cells, (ii, iii, iv) HeLa cells treated with the DCM fraction of the $\mathrm{CN}$ extract at $62.5,125$, and $250 \mu \mathrm{g} / \mathrm{mL}$, respectively.

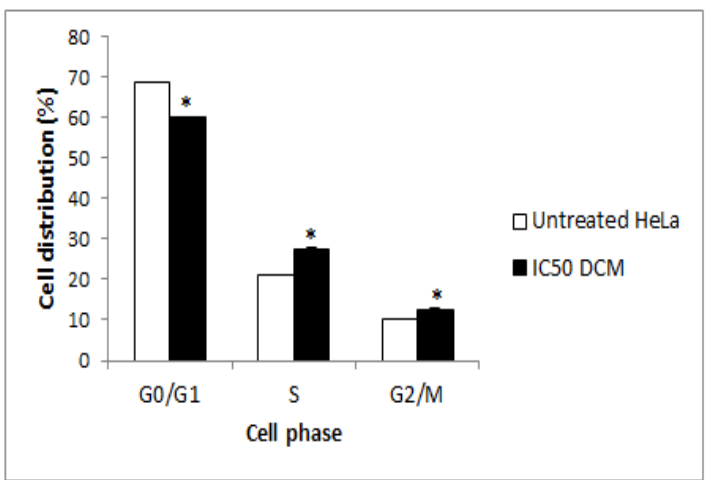

(B)

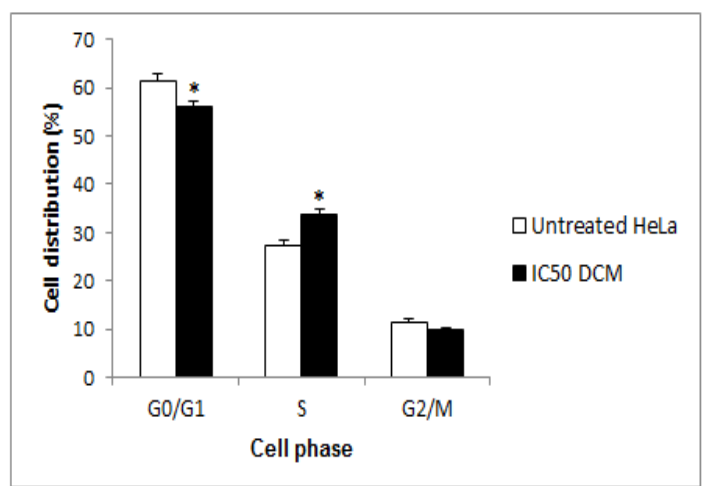

(C)

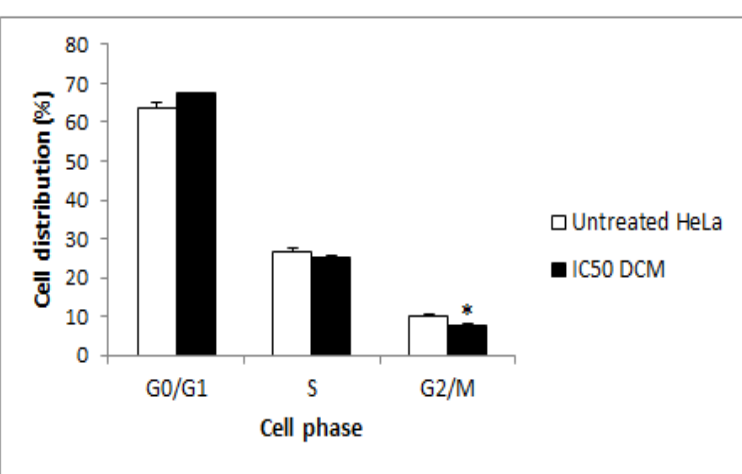

Figure 5. Effects of the DCM Fraction of the CN Leaf Extract on the Cell Cycle of HeLa Cells. The cells were treated at $70 \mu \mathrm{g} / \mathrm{mL}$ for (A) $24 \mathrm{~h}$, (B) $48 \mathrm{~h}$, and (C) $72 \mathrm{~h}$. Asterisks signify statistical significance at $\mathrm{p}<0.05$ compared to untreated HeLa cells. 
significant increase $(\mathrm{p}<0.05)$ in HeLa cells in the $\mathrm{S}$ and G2/M phases compared to the control group was detected after $24 \mathrm{~h}$ of treatment (Figure 5A). This increase was accompanied by a significant decrease $(p<0.05)$ of HeLa cells in the $\mathrm{G} 0 / \mathrm{G} 1$ phase. After $48 \mathrm{~h}$, a significant increase $(p<0.05)$ in HeLa cells in the $\mathrm{S}$ phase only was detected, and it was accompanied by a decrease in cells in the $\mathrm{G} 0$ / G1 phase (Figure 5B). After $72 \mathrm{~h}$, a significant decrease $(p<0.05)$ in the population of cells in the $\mathrm{G} 2 / \mathrm{M}$ phase was recorded (Figure 5C).

\section{GC-MS analysis of the DCM fraction}

The GC-MS analysis of the DCM fraction of $\mathrm{CN}$ leaves revealed high flavonoid content. Identification of the compounds was made by referring to the corresponding compound in the NIST library with a similarity index of at least $80 \%$. The biological potential of the identified compounds was determined by comparison with previously reported results. Table 2 shows the 28 phytochemical constituents identified in this study; the highest relative peak area was for N-(4-methoxyphenyl)-2hydroxyimino-acetamide (4.72\%). However, the identified phytochemicals belonged mainly to the fatty acid class, as it covered $20.29 \%$ of the total peak area.

\section{Discussion}

None of the $\mathrm{CN}$ extracts tested in this study were cytotoxic to HeLa cells as defined by the American National Cancer Institute's $\left(\mathrm{IC}_{50}:<30 \mu \mathrm{g} / \mathrm{mL}\right)$ criteria of cytotoxic activity of crude extracts. Of the extracts tested, the DCM fraction had the lowest $\mathrm{IC}_{50}$ value. This finding is in agreement with results of previous studies (Arullappan et al., 2014; Che Sulaiman et al., 2015; Ng et al., 2017; Yong et al., 2013) in which other non-polar and semi-polar extracts of $\mathrm{CN}$, such as chloroform, ethyl acetate, hexane, and petroleum ether, demonstrated higher antiproliferative activity than polar extracts (aqueous and methanol). This study was the first to report this result for the DCM fraction.

Flow cytometry data showed that the DCM fraction at $48 \mathrm{~h}$ affected the progression of apoptosis in a dose-dependent manner, whereby the lowest dose $(62.5$ $\mu \mathrm{g} / \mathrm{mL}$ ) induced the highest percentage of early apoptosis and the highest dose $(250 \mu \mathrm{g} / \mathrm{mL})$ resulted in the most cells in the late apoptosis stage. A previous study showed that cold aqueous and crude methanol $\mathrm{CN}$ leaf extracts induced apoptosis in a wild type BRAF melanoma cell line (D24) in a dose- and time-dependent manner (Fong, 2015). In another study, mouse hepatoma cells treated with $30 \%$ ethanol extracts of $\mathrm{CN}$ in low or high doses showed a significant decrease in the expression of PCNA and p-AKT (proliferation markers) and increased expression of BAX, Bcl2, caspase-3, and PAPR (apoptosis markers) (Huang et al., 2015). Ng et al., (2017) reported that high concentration $(>100 \mu \mathrm{g} / \mathrm{mL})$ of hexane extract from $\mathrm{CN}$ induced apoptosis in A549, CNE1, and HepG2 cell lines by upregulating activities of caspase $3 / 7,8$, and 9. Morphological changes of treated HeLa cells, such as cell shrinkage, apoptotic body formation, and DNA fragmentation, also were indicative of apoptosis.

Cell cycle analysis showed that the DCM fraction induced S and G2/M phase arrest after $24 \mathrm{~h}$ of treatment and S-phase only after $48 \mathrm{~h}$ of treatment. DNA synthesis or duplication of chromosome occurs during S-phase, whereas the G2/M phase is a gap state $(\mathrm{G} 2)$ in which the cell with newly replicated DNA continues to grow to ensure that everything is ready to enter the mitosis (M) phase. At the M stage, the cell stops growing and divides its copied DNA into two daughter cells. The observed S phase cell cycle arrest, which indicates decreasing rate of DNA synthesis, might explain the mechanism of the antiproliferative effect by the DCM fraction at $48 \mathrm{~h}$ of treatment. In a previous study, the hexane fraction of $\mathrm{CN}$ increased the sub-G1 populations of CNE1, HepG2, and A549 cells in a dose-related manner, while the G0/G1 and $\mathrm{G} 2 / \mathrm{M}$ populations showed a corresponding decrease (Ng et al., 2017). Thus, the antiproliferative mechanism may differ depending on the type of cancer cell, the tested compound, and the different natural products present in the extract, which are likely to vary at different stages of the cell cycle (Peng et al., 2015).

Twenty-eight volatile components of the DCM fraction were identified via GC-MS analysis, and fatty acids were the main components. Some of the same phytoconstituents were reported in other GC-MS studies of $\mathrm{CN}$, including 1,2-benzene dicarboxylic acid mono(2-ethylhexyl) ester, 9,12,15-octadecatrienoic acid methyl ester (Z,Z,Z)-, n-hexadecanoic acid, octadecanoic acid methyl ester, 9,12-octadecadienoic acid (Z,Z)-, phytol, stigmasterol, and vitamin E (Abdul Rahim et al., 2016; Alam et al., 2017; Mustapa et al., 2015; Ng et al., 2017; Teoh et al., 2017; Yong et al., 2013). Some of the compounds identified in this study were previously reported to have antiproliferative (cytotoxic and antioxidant) activity against tumor cell lines, such as 1,2-benzenedicarboxylic acid mono(2-ethylhexyl) ester (Krishnan et al., 2014), 4-((1E)-3-hydroxy-1-propenyl)-2-methoxyphenol (Duke, 1992), phytol (Lakshmi et al., 2016; Santos et al., 2013, Song and Cho, 2015), stigmasterol (Gao et al., 2008; Huang et al., 2009), and vitamin E (Campbell et al., 2006; Howard et al., 2011).

Further studies are needed to discover the mechanisms underlying the antiproliferative activity of $C$. nutans extracts against cancer cell lines and to identify specific bioactive compounds that are responsible for the observed activities. This study shows that different solvent extracts of $\mathrm{CN}$ can have different antiproliferative activities against HeLa cells. Moreover, the extraction technique and fraction used can affect the outcome, as the DCM fraction in this study had a lower $\mathrm{IC}_{50}$ value against HeLa cells (70 $\mu \mathrm{g} / \mathrm{mL}$ ) than has been reported in previous studies. The potent phytochemical constituents of the DCM fraction may contribute to the antiproliferative activity against HeLa cells, and this information may be useful for the development of a novel anticancer therapy.

\section{Funding Statement}

This work was funded and supported by a FRGS grant (203/CIPPT/6711340) from the Ministry of Higher 
Education, Government of Malaysia and USM Bridging Grant (304/CIPPT/6316239) to Hasni Arsad.

\section{Acknowledgements}

The authors thank A.P. Dr. Rahmad Zakaria for plant identification, Mr. Ahmad Firdaus Abdul Hadi for assistance in handling the plant extraction apparatus, and Ms. Ira Maya Sophia Nordin for assistance with the apoptosis and cell cycle analyses.

\section{References}

Abdul Rahim MH, Zakaria ZA, Mohd Sani MH, et al (2016). Methanolic extract of Clinacanthus nutans exerts antinociceptive activity via the opioid/nitric oxide-mediated, but cGMP-independent, pathways. Evid Based Complement Alternat Med, Article ID, 1494981.

Alam MA, Zaidul ISM, Ghafoor K, et al (2017). Identification of bioactive compounds with $\mathrm{GC}-\mathrm{Q}-\mathrm{TOF}-\mathrm{MS}$ in the extracts from Clinacanthus nutans using subcritical carbon dioxide extraction. Sep Sci Technol, 52, 852-63.

Arullappan S, Rajamanickam P, Thevar N, Kodimani CC (2014) In vitro screening of cytotoxic, antimicrobial and antioxidant activities of Clinacanthus nutans (Acanthaceae) leaf extracts. Trop J Pharm Res, 13, 1455-61.

Bendale Y, Bendale V, Paul S (2017). Evaluation of cytotoxic activity of platinum nanoparticles against normal and cancer cells and its anticancer potential through induction of apoptosis. Integr Med Res, 6, 141-8.

Bray F, Ferlay J, Soerjomataram I, et al (2018). Global cancer statistics 2018: GLOBOCAN estimates of incidence and mortality worldwide for 36 cancers in 185 countries. CA Cancer J Clin, 0, 1-31.

Campbell SE, Stone WL, Lee S, et al (2006). Comparative effects of RRR-alpha- and RRR-gamma-tocopherol on proliferation and apoptosis in human colon cancer cell lines. BMC Cancer, 6, 13.

Che Sulaiman IS, Basri M, Chan KW, et al (2015). In vitro antioxidant, cytotoxic and phytochemical studies of Clinacanthus nutans Lindau leaf extracts. Afr J Pharm Pharmacol, 9, 861-74.

Duke, JA (1992). Handbook of phytochemical constituents of GRAS herbs and other economic plants. Boca Raton (FL): CRC Press. [accessed 2017 Dec 12]. http://phytochem.nal. usda.gov.

Fong S (2015). Genetic, phytochemical and bioactivity studies of Clinacanthus nutans (Burm. f.) Lindau (Acanthaceae) [Thesis]. Victoria (Australia): Applied Science, RMIT University.

Gao Z, Malonev DJ, Dedkova LM, Hecht SM (2008). Inhibitors of DNA polymerase beta: activity and mechanism. Bioorg Med Chem, 16, 4331-40.

Howard AC, McNeil AK, McNeil PL (2011). Promotion of plasma membrane repair by vitamin E. Nat Commun, 2, 597.

Huang D, Guo W, Gao J, Chen J, Olatunji JO (2015). Clinacanthus nutans (Burm. f.) Lindau ethanol extract inhibits hepatoma in mice through upregulation of the immune response. Molecules, 20, 17405-28.

Huang JG, Zhou LJ, Xu HH, Li WO (2009). Insecticidal and cytotoxic activities of extracts of Cacalia tangutica and its two active ingredients against Musca domestica and Aedes albopictus. J Econ Entomol, 102, 1444-7.

Jayavasu C, Dechatiwongse T, Balachandra K (1992). Virucidal activity of Clinacanthus nutans Lindau extracts against herpes simplex virus type-2: In vitro study. Bull Depart
Med Sci, 34, 153-8.

Khoo LW, Mediani A, Zolkeflee NKZ, et al (2015). Phytochemical diversity of Clinacanthus nutans extracts and their bioactivity correlations elucidated by NMR based metabolomics. Phytochem Lett, 14, 123-33.

Krishnan K, Mani A, Jasmine S (2014). Cytotoxic activity of bioactive compound 1,2- benzene dicarboxylic acid, mono 2- ethylhexyl ester extracted from a marine derived Streptomyces sp. VITSJK8. Int J Mol Cell Med, 3, 246-54.

Lakshmi SLD, Bharadwaj S, Parveen KS (2016). Anticancer activity of phytol purified from Gracilaria edulis against human breast cancer cell line (MCF-7). Int J Curr Sci, 19, $36-46$.

Mustapa AN, Martin Á, Mato RB, Cocera MJ (2015). Extraction of phytocompounds from the medicinal plant Clinacanthus nutans Lindau by microwave-assisted extraction and supercritical carbon dioxide extraction. Ind Crops Prod, 74, 83-94.

$\mathrm{Ng}$ PY, Chye SM, Ng CH, et al (2017). Clinacanthus nutans hexane extracts induce apoptosis through a caspase-dependent pathway in human cancer cell lines. Asian Pac J Cancer Prev, 18, 917-26.

Peng X, Zhuang DD, Guo QS (2015). Induction of S phase arrest and apoptosis by ethyl acetate extract from Tetrastigma hemsleyanum in human hepatoma HepG2 cells. Tumour Biol, 36, 2541-50.

Poonthananiwatkul B, Lim RHM, Howard RL, Pibanpaknitee P, Williamson EM (2015). Traditional medicine use by cancer patients in Thailand. J Ethnopharmacol, 168, 100-7.

Quah SY, Chin JH, Akowuah GA, et al (2017). Cytotoxicity and cytochrome P450 inhibitory activities of Clinacanthus nutans. Drug Metabol Pers Ther, 32, 59-65.

Sakdarat S, Shuyprom A, Na Ayudhya TD, Waterman PG, Karagianis G (2006). Chemical composition investigation of the Clinacanthus nutans Lindau leaves. Thai J Phytopharm, 13, 13-24.

Santos CCMP, Salvadori MS, Mota VG, et al (2013). Antinociceptive and antioxidant activities of phytol in vivo and in vitro models. Neurosci J, Article ID: 949452.

Siew YY, Zareisedehizadeh S, Seetoh WG, et al (2014). Ethnobotanical survey of usage of fresh medicinal plants in Singapore. J Ethnopharmacol, 155, 1450-66.

Skehan P, Storeng R, Scudiero D, et al (1998). New colorimetric cytotoxicity assay for anticancer-drug screening. $J$ Natl Cancer I, 82, 1107-18.

Song YW, Cho SK (2015). Phytol induces apoptosis and ROS-mediated protective autophagy in human gastric adenocarcinoma AGS cells. Biochem Anal Biochem, 4, 211.

Teoh PL, Cheng AYF, Liau M, et al (2017). Chemical composition and cytotoxic properties of Clinacanthus nutans root extracts. Pharm Biol, 55, 394-401.

Teshima K, Kaneko T, Ohtani K, et al (1997). C-glycosyl flavones from Clinacanthus nutans. Nat Med, 51, 557.

Thawaranantha D, Balachandra K, Jongtrakulsiri S, et al (1992). In vitro antiviral activity of Clinacanthus nutans on varicellazoster virus. Siriraj Hosp Gaz Thailand, 44, 285-91.

Uawonggul N, Chaveerach A, Thammasirirak S, et al (2006). Screening of plants acting against Heterometrus laoticus scorpion venom activity on fibroblast cell lysis. J Ethnopharmacol, 103, 201-7.

World Health Organization (2018). Cancer: Cervical cancer [accessed 2018 October 13]. http://www.who.int/cancer/ prevention/diagnosis-screening/cervical-cancer/en/.

Yin SY, Wei WC, Jian FY, Yang NS (2013). Therapeutic applications of herbal medicines for cancer patients. Evid Based Complement Alternat Med, 2013, 302426.

Yong YK, Tan JJ, Teh SS, et al (2013). Clinacanthus nutans 
DOI:10.31557/APJCP.2019.20.2.601

extracts are antioxidant with antiproliferative effect on cultured human cancer cell lines. J Evidence-Based Complementary Altern Med, Article ID, 462751.

\section{(ब) $(\mathbb{8}$}

This work is licensed under a Creative Commons AttributionNon Commercial 4.0 International License. 